\title{
Evaluation of Dose Distributions Recalculated with Per-field Measurement Data under the Condition of Respiratory Motion during IMRT for Liver Cancer
}

\author{
Ju-Young Song ${ }^{\dagger}$, Yong-Hyeob Kim, Jae-Uk Jeong ${ }^{*}$, Mee Sun Yoon ${ }^{\dagger}$, Sung-Ja Ahn ${ }^{\dagger}$, \\ Woong-Ki Chung ${ }^{\dagger}$, Taek-Keun $\mathrm{Nam}^{\dagger}$ \\ *Department of Radiation Oncology, Chonnam National University Hwasun Hospital, Hwasun, \\ ${ }^{\dagger}$ Department of Radiation Oncology, Chonnam National University Medical School, Gwangju, Korea
}

\begin{abstract}
The dose distributions within the real volumes of tumor targets and critical organs during internal target volume-based intensity-modulated radiation therapy (ITV-IMRT) for liver cancer were recalculated by applying the effects of actual respiratory organ motion, and the dosimetric features were analyzed through comparison with gating IMRT (Gate-IMRT) plan results. The ITV was created using MIM software, and a moving phantom was used to simulate respiratory motion. The doses were recalculated with a 3 dose-volume histogram (3DVH) program based on the per-field data measured with a MapCHECK2 2-dimensional diode detector array. Although a sufficient prescription dose covered the PTV during ITV-IMRT delivery, the dose homogeneity in the PTV was inferior to that with the Gate-IMRT plan. We confirmed that there were higher doses to the organs-at-risk (OARs) with ITV-IMRT, as expected when using an enlarged field, but the increased dose to the spinal cord was not significant and the increased doses to the liver and kidney could be considered as minor when the reinforced constraints were applied during IMRT plan optimization. Because the Gate-IMRT method also has disadvantages such as unsuspected dosimetric variations when applying the gating system and an increased treatment time, it is better to perform a prior analysis of the patient's respiratory condition and the importance and fulfillment of the IMRT plan dose constraints in order to select an optimal IMRT method with which to correct the respiratory organ motional effect.
\end{abstract}

Key Words: Respiratory organ motion, IMRT, Internal target volume (ITV), Gating system, 3DVH

\section{Introduction}

Intensity-modulated radiation therapy (IMRT) has been used effectively in complicated clinical cases that require improved dose distribution to tumor targets and reduced doses to normal tissues and critical organs near the tumor.

Although IMRT has been most often performed in cases of head and neck and prostate cancer in which the tumor motion is very small and within a limited range, this technique has also been applied to tumors located in the abdomen and chest,

Received 8 May 2014, Revised 3 June 2014, Accepted 9 June 2014 Correspondence: Taek-Keun Nam (tknam@chonnam.ac.kr) Tel: 82-61-379-7224, Fax: 82-61-379-7249

(C) This is an Open-Access article distributed under the terms of the Creative Commons Attribution Non-Commercial License (http://creativecommons.org/licenses/by-nc/3.0) which permits unrestricted non-commercial use, distribution, and reproduction in any medium, provided the original work is properly cited. including liver cancer and lung cancer which are affected by respiratory organ motion. Many studies on dosimetric errors during IMRT beam delivery consequent to respiratory organ motion have been conducted, and some practical methods have been devised to resolve these errors. ${ }^{1-8)}$

An active breathing coordinator $(\mathrm{ABC})$ system and real-time position management (RPM) respiratory gating system are typically applied to clinical cases in order to reduce the respiratory organ motional effects. These methods often require the patient's cooperation with controlling their regulatory respiration pattern, and the motional correlation between the external marker and internal organ should be uniform in the RPM gating system. These requirements are very difficult to achieve in actual clinical practice, which can introduce more errors in cases involving IMRT, given the complicated dose distributions delivered through the accurate movements of a multi-leaf 
collimator (MLC). IMRT administered through sliding window-type MLC movements can lead to substantial errors in the gating method due to the possible dosimetric inconstancy and inaccuracy of the MLC position during the repeated-beam on-off process. ${ }^{9)}$

Another conventional way to consider the organ motional effect without using a beam on-off gating system is to apply the entire range of respiratory organ motion as a margin when delineating the planning target volume (PTV). The accurate motion range can be applied to the internal target volume (ITV) using 4-dimensional computed tomography (4DCT), which can minimize unnecessary margins when delineating the PTV. ${ }^{10-13)}$ When creating an IMRT plan based on the 4DCTcontoured ITV, there is no need to apply the gating method and stable IMRT can be performed without dosimetric error, due to the beam on-off process. However, a disadvantage of the ITV method is that the dose to the organ at risk (OAR) near the PTV might be increased as a result of the treatment field, which is larger than that used in the gating method. It is also difficult to analyze the accurate dosimetric distributions in the real PTV and OARs using ITV because the IMRT plan is created using an inflated PTV and OARs, which differ from the actual volumes.

In this study, we devised a method for calculating the dose distributions in the real PTV and OARs when an ITV-based IMRT (ITV-IMRT) plan was delivered under the condition of actual respiratory organ motion, and analyzed the calculated dosimetric data through comparison with a gating IMRT (Gate-IMRT) plan. The ITV-IMRT plans for this study were created from 4DCT scans of liver cancer patients, and an accurate ITV that applied the entire motion range was delineated. The doses in the patients' CT data were recalculated based on the measured ITV-IMRT doses delivered under the condition of respiratory motion in each patient. The calculated dose distributions in the actual volumes of the PTV and OARs were compared with the results of the Gate-IMRT plan and analyzed for the application of the proper IMRT method for treating liver tumors, which includes a variable motional aspect due to the differences in the patients' respiratory conditions.

\section{Materials and Methods}

The 4DCT data for 10 patients who had been treated with Gate-IMRT for liver cancer were selected to create ITV-IMRT plans. The 4DCT data were acquired with a BrightSpeed CT scanner (GE Medical Systems, Milwaukee, WI), and retrospectively reconstructed 10-phase CT data were transferred to the MIM program (MIM Software Inc., Cleveland, $\mathrm{OH}$ ) to generate the ITV and planning OAR volume (PRV). The CTV and OAR contours in 50\%-phase CT for the Gate-IMRT plan were propagated to the other phase CT using a deformable registration algorithm, and all contours from each phase CT were combined into a final ITV and PRVs.

The PTV was generated by adding a $0.5-\mathrm{cm}$ setup margin to the ITV, and all ITV-IMRT plans were made using 7 fixed 10-MV X-ray beams from a Clinac iX linear accelerator (Varian Medical Systems, Palo Alto, CA); these plans used the same gantry angles as did Gate-IMRT plans. The Eclipse radiation treatment planning (RTP) system (Varian Medical Systems, Palo Alto, CA) was employed, and the same dosimetric constraints were used during the optimization process for IMRT planning. The prescription dose to the PTV was 50 Gy, applied in 25 fractions, and the optimization constraints for the PTV were that the $95 \%$ isodose (prescription) surface had to cover $95 \%$ of the PTV and that no portion of the PTV could receive more than $110 \%$ of the prescription dose. The OARs considered during the optimization were the liver, kidney, and spinal cord. The liver constraint was that the volume irradiated with $>30$ Gy should comprise $<30 \%$ of the total volume. The kidney constraint was that the volume irradiated with $>20$ Gy should comprise $<20 \%$ of the total volume. The dose limit to the spinal cord was $45 \mathrm{~Gy}$.

The Dynamic Platform Model 008PL (CIRS Inc., Norfolk, VA), which can simulate respiratory motion, was used to apply the same respiratory motional effects in each patient during ITV-IMRT beam delivery. The period and range of respiratory motion in the region of tumor were measured in all patients from 4DCT-generated movie data, and the same period and range were applied when operating the dynamic phantom to realize coincident respiratory conditions in each patient. In this study, single motional range in the superior-inferior direc- 
tion was measured and applied to the phantom simulation because the dynamic phantom could move in only 1-direction, and the greatest changes in respiratory motion usually occurred in the superior-inferior direction.

The per-field measurement for verifying the dose distribution in each IMRT filed under the condition of respiratory motion was performed using a MapCHECK2 2-dimensional diode detector array (SunNuclear, Melbourne, FL), which was laid on the dynamic phantom as shown in Fig. 1. The delivered dose distribution in each patient's CT was recalculated using a 3 dose-volume histogram program (3DVH; SunNuclear, Melbourne, FL) and applying the per-field measurement data. The 3DVH was used because the program is the only verified method that can calculate internal dose distribution of patient with the $2 \mathrm{D}$ data measured by MapCHECK2. The DVHs of the actual PTV and OARs during ITV-IMRT beam delivery under the condition of respiratory organ motion were calculated with a 3DVH and compared with the DVHs calculated for the Gate-IMRT plan to analyze the organ motional effect on dosimetric changes during ITV-IMRT delivery. The overall process of this study is summarized in Fig. 2.

\section{Results}

An example of ITV delineation with the MIM program is shown in Fig. 3, and proper contour expansion can be verified

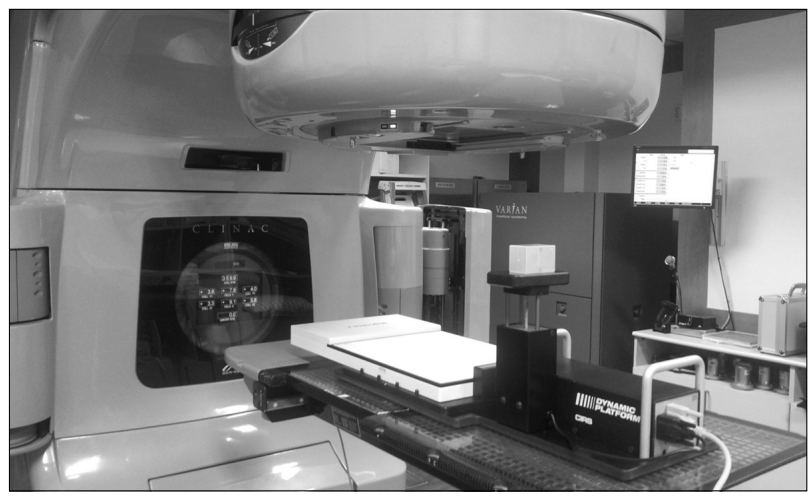

Fig. 1. MapCHECK2 laid on the dynamic moving phantom for the per-field measurement of ITV-IMRT under the condition of respiratory motion.

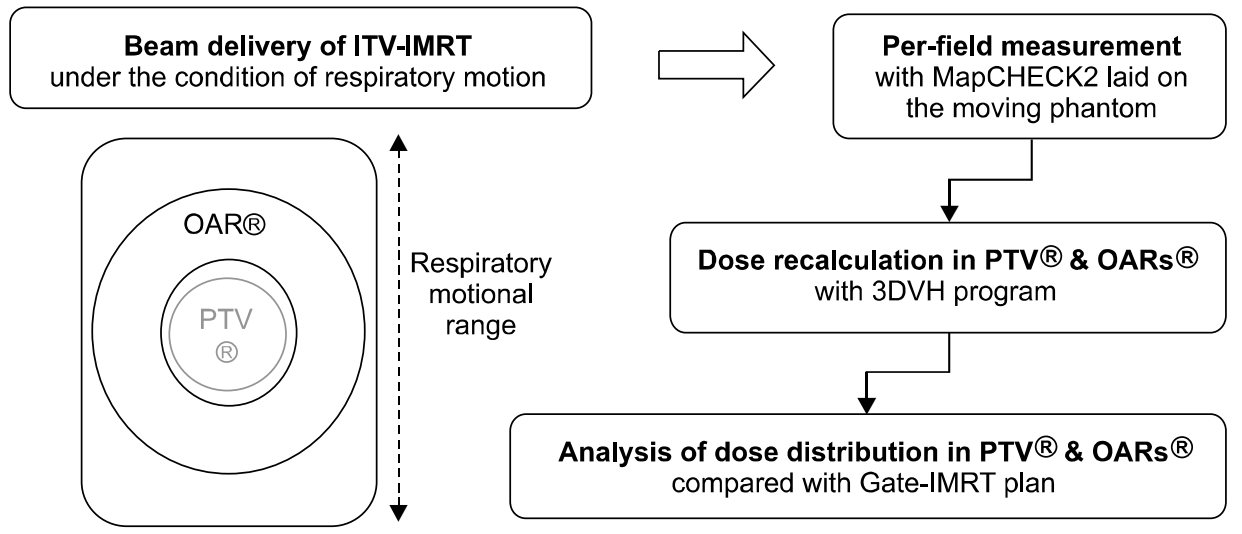

${ }^{*}$ PTV ${ }^{\circledR}:$ Real PTV removed the motional effect, OARs ${ }^{\circledR}:$ Real OARs removed the motional effect

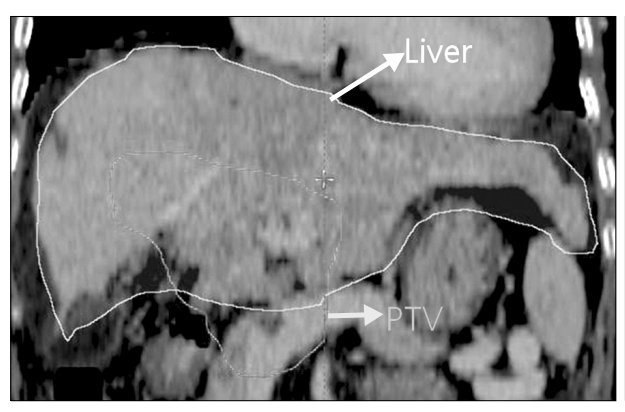

Fig. 2. Diagram of the overall study process.
Fig. 3. Example of PTV and OARs in ITV-IMRT plan delineated in MIM program reflecting the respiratory motional effect. 
Table 1. Volume comparison of PTV and OARs between ITV-IMRT plan and Gate-IMRT plan with information on the period and range of respiratory motion in each patient.

\begin{tabular}{|c|c|c|c|c|c|c|c|c|c|c|}
\hline \multirow{2}{*}{ Patients } & \multicolumn{2}{|c|}{ PTV $\left[\mathrm{cm}^{3}\right]$} & \multicolumn{2}{|c|}{ Liver $\left[\mathrm{cm}^{3}\right]$} & \multicolumn{2}{|c|}{ Lt-kidney $\left[\mathrm{cm}^{3}\right]$} & \multicolumn{2}{|c|}{ Rt-kidney $\left[\mathrm{cm}^{3}\right]$} & \multirow{2}{*}{$\begin{array}{c}\text { Respiration } \\
\text { period } \\
\text { [sec] }\end{array}$} & \multirow{2}{*}{$\begin{array}{c}\text { Respiratory } \\
\text { motional } \\
\text { range }[\mathrm{cm}]\end{array}$} \\
\hline & Gate-IMRT & ITV-IMRT & Gate-IMRT & ITV-IMRT & Gate-IMRT & ITV-IMRT & Gate-IMRT & ITV-IMRT & & \\
\hline $\mathrm{A}$ & 642.0 & 711.2 & 1785.9 & 1965.9 & 238.8 & 270.2 & 196.8 & 221.2 & 9.0 & 1.7 \\
\hline B & 273.8 & 327.8 & 1846.3 & 2073.9 & 145.8 & 170.7 & 141.9 & 155.7 & 5.0 & 1.8 \\
\hline $\mathrm{C}$ & 49.5 & 58.7 & 1325.3 & 1471.7 & 161.3 & 191.5 & 153.0 & 174.5 & 6.0 & 1.2 \\
\hline $\mathrm{D}$ & 573.0 & 612.5 & 1053.3 & 1261.6 & 240.3 & 271.5 & 185.6 & 214.8 & 7.0 & 1.5 \\
\hline $\mathrm{E}$ & 2021.9 & 2100.3 & 2506.2 & 2752.3 & 187.2 & 215.8 & 175.1 & 183.1 & 7.0 & 1.3 \\
\hline F & 683.2 & 762.5 & 2005.1 & 2148.9 & 418.6 & 478.9 & 213.5 & 238.7 & 4.0 & 1.4 \\
\hline G & 1133.9 & 1286.2 & 1453.4 & 1618.6 & 220.5 & 251.7 & 231.7 & 258.4 & 5.0 & 1.5 \\
\hline $\mathrm{H}$ & 465.8 & 529.9 & 1326.1 & 1518.1 & 167.6 & 189.6 & 154.4 & 184.8 & 5.0 & 1.5 \\
\hline I & 433.4 & 532.0 & 938.1 & 1115.9 & 201.2 & 239.9 & 165.2 & 199.5 & 7.0 & 1.8 \\
\hline $\mathrm{J}$ & 440.6 & 527.8 & 1438.6 & 1726.8 & 147.5 & 190.4 & 156.2 & 196.8 & 6.0 & 1.2 \\
\hline
\end{tabular}

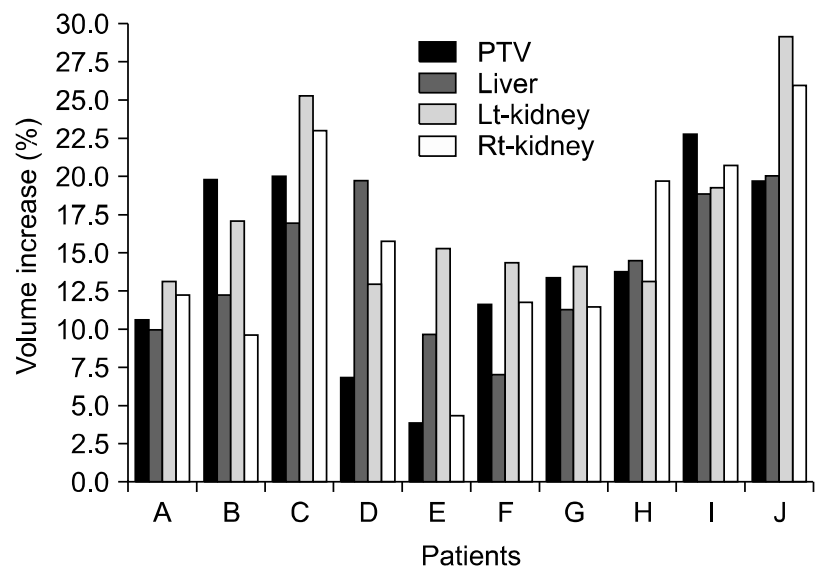

Fig. 4. Volume increase rate of PTV and OARs in ITV-IMRT plan compared with the volume in Gate-IMRT plan.

based on the shapes of the kidney and liver. The ITV-IMRT plan volumes of the PTV and OARs of 10 patients are listed in Table 1 along with the respiration periods and tumor motion ranges of each patient. The rates of increase in the PTV and OARs, compared with the volumes obtained in the GateIMRT plans, are shown in a graph in Fig. 4. The ITV-IMRT volume increases due to the respiratory motion range were the same for both the PTV and OARs, but the correlation trends were different. Although Pearson's coefficient value was positive when calculated for the correlation between the motion range and the PTV increase, a negative value was obtained for the OARs, indicating that, in contrast to the PTV, the volume increase in the OARs was not proportional to the motion range.

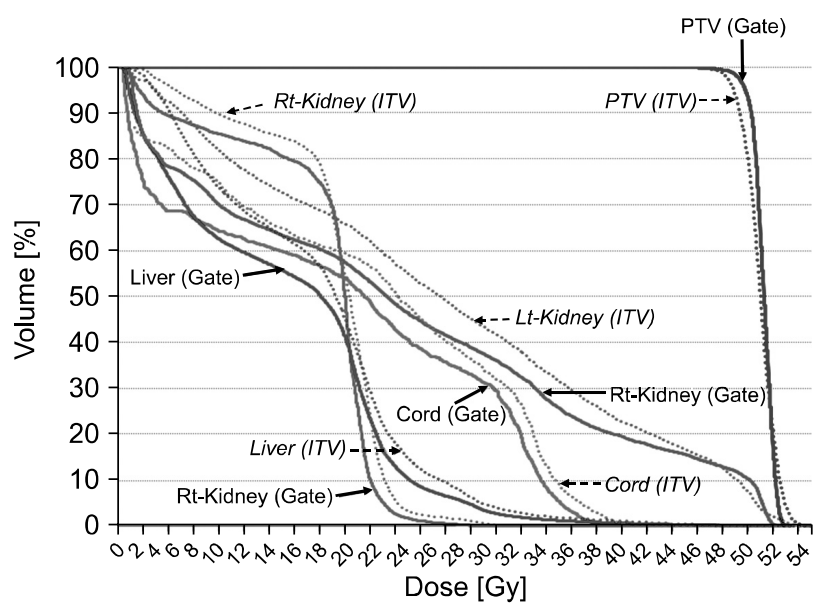

Fig. 5. Example of the DVH comparison between the recalculated dose in the ITV-IMRT beam delivery and the DVH of Gate-IMRT plan.

An example of a DVH produced from the recalculated dose obtained from a patient's CT and based on the measured perfield data under the condition of respiratory motion is shown in Fig. 5, along with a comparison with the DVH from a GateIMRT plan. Results of comparisons between the 2 DVHs at the specific points are provided in Tables $2 \sim 5$. The DVH differences in the PTV are verified in Fig. 6, which shows that the PTV doses increased more with the ITV-IMRT beam delivery than with the Gate-IMRT plan. The average dose increases were $3.85 \pm 1.79$ Gy for the maximum dose (Dmax) to the PTV and $1.30 \pm 0.96$ Gy for the mean dose (Dmean). The average rate of increase in the PTV volume that received $>47.5$ 
Table 2. Comparison of PTV's DVH on the specific points between the beam delivery of ITV-IMRT and Gate-IMRT plan.

\begin{tabular}{|c|c|c|c|c|c|c|}
\hline \multirow{2}{*}{ Patients } & \multicolumn{2}{|c|}{ PTV mean-dose [Gy] } & \multicolumn{2}{|c|}{ PTV max-dose [Gy] } & \multicolumn{2}{|c|}{ PTV V V7.5Gy $[\%$ vol] } \\
\hline & Gate-IMRT & ITV-IMRT & Gate-IMRT & ITV-IMRT & Gate-IMRT & ITV-IMRT \\
\hline A & 51.19 & 50.95 & 53.21 & 55.14 & 99.66 & 99.40 \\
\hline B & 50.78 & 52.84 & 52.62 & 55.46 & 99.94 & 100.00 \\
\hline $\mathrm{C}$ & 51.92 & 55.04 & 53.53 & 56.89 & 100.00 & 100.00 \\
\hline $\mathrm{D}$ & 50.53 & 51.24 & 52.86 & 54.49 & 99.82 & 99.29 \\
\hline E & 49.61 & 50.61 & 53.67 & 59.21 & 98.33 & 97.63 \\
\hline $\mathrm{F}$ & 49.56 & 51.74 & 53.52 & 57.74 & 88.95 & 98.87 \\
\hline G & 48.95 & 49.81 & 52.22 & 55.26 & 94.88 & 95.75 \\
\hline $\mathrm{H}$ & 50.13 & 50.75 & 52.37 & 55.22 & 99.02 & 90.23 \\
\hline I & 49.64 & 51.19 & 54.83 & 61.36 & 67.32 & 73.57 \\
\hline $\mathrm{J}$ & 51.28 & 52.47 & 53.29 & 56.83 & 99.88 & 99.70 \\
\hline
\end{tabular}

Table 3. Comparison of liver's DVH on the specific points between the beam delivery of ITV-IMRT and Gate-IMRT plan.

\begin{tabular}{|c|c|c|c|c|c|c|}
\hline \multirow{2}{*}{ Patients } & \multicolumn{2}{|c|}{ Liver mean-dose [Gy] } & \multicolumn{2}{|c|}{ Liver max-dose [Gy] } & \multicolumn{2}{|c|}{ Liver $\mathrm{D}_{30 \%}[\mathrm{~Gy}]$} \\
\hline & Gate-IMRT & ITV-IMRT & Gate-IMRT & ITV-IMRT & Gate-IMRT & ITV-IMRT \\
\hline $\mathrm{A}$ & 13.46 & 15.68 & 51.63 & 52.36 & 19.22 & 19.97 \\
\hline B & 21.92 & 25.80 & 52.62 & 56.41 & 29.08 & 33.26 \\
\hline $\mathrm{C}$ & 7.46 & 9.56 & 53.13 & 56.43 & 7.43 & 12.90 \\
\hline $\mathrm{D}$ & 8.05 & 11.10 & 52.13 & 53.24 & 9.23 & 14.83 \\
\hline $\mathrm{E}$ & 40.83 & 42.26 & 53.67 & 56.55 & 49.61 & 50.64 \\
\hline $\mathrm{F}$ & 30.40 & 34.02 & 53.52 & 57.74 & 46.95 & 50.27 \\
\hline G & 23.29 & 25.23 & 52.17 & 54.70 & 27.79 & 29.52 \\
\hline $\mathrm{H}$ & 21.57 & 22.78 & 54.43 & 55.14 & 30.37 & 31.18 \\
\hline I & 28.91 & 30.40 & 54.83 & 61.36 & 48.78 & 50.12 \\
\hline $\mathrm{J}$ & 27.83 & 28.80 & 53.29 & 56.83 & 35.80 & 37.04 \\
\hline
\end{tabular}

Gy, (95\% of the prescribed dose) was $0.66 \pm 4.85 \%$. Fig. 7 shows the dose homogeneity within a PTV, which was calculated as a homogeneity index (HI) using equation (1). ${ }^{14)}$ The average HI of the PTV during ITV-IMRT delivery was $13.66 \pm$ $9.32 \%$ which was slightly inferior to the average HI value of, $10.10 \pm 6.98 \%$, for the Gate-IMRT plan.

$H I=\frac{\left(D_{2 \%}-D_{98 \%}\right)}{\left(D_{\text {prescription }}\right)} \times 100 \%$

$D_{2 \%}$ : the dose to the $2 \%$ of the target volume, as displayed on the $D V H$

$D_{98 \%}$ : the dose to the $98 \%$ of the volume as displayed on the cumulative DVH

$D_{\text {prescription: }}$ the prescription dose

The results of a comparison of the OAR DVH differences are shown in Fig. 8, 9, and 10. Fig. 8 shows the results of a liver comparison, in which a higher dose was irradiated during ITV-IMRT delivery than with the Gate-IMRT plan. The average dose increases were $2.93 \pm 1.80 \mathrm{~Gy}$ for the $\mathrm{D}_{\max }, 2.47 \pm 1.16$ Gy for the $\mathrm{D}_{\text {mean }}$, and $2.31 \pm 1.66 \mathrm{~Gy}$ for the dose to $30 \%$ of the liver volume on the cumulative DVH $\left(\mathrm{D}_{30 \%}\right)$. Fig. 9 shows that the results of a kidney comparison, in which higher doses were also observed during ITV-IMRT delivery. The average dose increases to the left kidney were $1.66 \pm 2.09$ Gy for the $\mathrm{D}_{\max }, 1.12 \pm 0.89 \mathrm{~Gy}$ for the $\mathrm{D}_{\text {mean }}$, and $1.33 \pm 0.87$ Gy for the dose to $20 \%$ of the kidney volume $\left(\mathrm{D}_{20 \%}\right)$. The average dose increases to the right kidney were $1.97 \pm 1.13$ Gy for the $D_{\max }$, $1.45 \pm 0.81$ Gy for the $\mathrm{D}_{\text {mean }}$, and $1.90 \pm 1.82$ Gy for the $\mathrm{D}_{20 \%}$. Higher irradiation doses were also delivered to the spinal cord during ITV-IMRT delivery, as shown in Fig. 10; the average dose increases were $1.22 \pm 1.32$ Gy for the $D_{\max }$ and $1.44 \pm 0.84$ Gy for the $D_{\text {mean }}$. 
Table 4. Comparison of kidney's DVH on the specific points between the beam delivery of ITV-IMRT and Gate-IMRT plan.

\begin{tabular}{|c|c|c|c|c|c|c|}
\hline \multirow{2}{*}{ Patients } & \multicolumn{2}{|c|}{ Lt-kidney mean-dose [Gy] } & \multicolumn{2}{|c|}{ Lt-kidney max-dose [Gy] } & \multicolumn{2}{|c|}{ Lt-kidney $\mathrm{D}_{20 \%}[\mathrm{~Gy}]$} \\
\hline & Gate-IMRT & ITV-IMRT & Gate-IMRT & ITV-IMRT & Gate-IMRT & ITV-IMRT \\
\hline A & 22.72 & 26.07 & 52.52 & 54.18 & 39.48 & 42.39 \\
\hline $\mathrm{B}$ & 5.54 & 6.92 & 24.17 & 29.21 & 7.58 & 9.09 \\
\hline $\mathrm{C}$ & 1.52 & 2.24 & 14.14 & 16.81 & 1.12 & 3.03 \\
\hline $\mathrm{D}$ & 15.71 & 16.54 & 44.53 & 46.69 & 18.86 & 20.05 \\
\hline $\mathrm{E}$ & 7.09 & 8.09 & 24.38 & 24.55 & 18.22 & 19.05 \\
\hline $\mathrm{F}$ & 0.79 & 1.45 & 5.42 & 6.80 & 0.90 & 3.38 \\
\hline G & 12.57 & 14.31 & 43.48 & 46.17 & 19.35 & 20.07 \\
\hline $\mathrm{H}$ & 7.57 & 8.25 & 29.53 & 31.00 & 13.46 & 13.91 \\
\hline I & 0.74 & 1.22 & 7.11 & 11.28 & 0.89 & 1.93 \\
\hline $\mathrm{J}$ & 2.58 & 2.94 & 19.14 & 19.28 & 5.16 & 5.43 \\
\hline \multirow{2}{*}{ Patients } & \multicolumn{2}{|c|}{ Rt-kidney mean-Dose [Gy] } & \multicolumn{2}{|c|}{ Rt-kidney max-Dose [Gy] } & \multicolumn{2}{|c|}{ Rt-kidney $\mathrm{D}_{20 \%}[\mathrm{~Gy}]$} \\
\hline & Gate-IMRT & ITV-IMRT & Gate-IMRT & ITV-IMRT & Gate-IMRT & ITV-IMRT \\
\hline A & 15.98 & 17.10 & 28.68 & 31.63 & 19.33 & 20.27 \\
\hline B & 11.87 & 14.21 & 34.53 & 35.21 & 16.92 & 17.85 \\
\hline $\mathrm{C}$ & 5.27 & 6.40 & 20.96 & 23.14 & 14.65 & 16.36 \\
\hline $\mathrm{D}$ & 14.40 & 15.51 & 46.97 & 49.73 & 19.07 & 20.67 \\
\hline $\mathrm{E}$ & 10.56 & 13.38 & 51.32 & 53.00 & 19.14 & 23.55 \\
\hline $\mathrm{F}$ & 5.81 & 8.33 & 31.05 & 34.17 & 12.64 & 18.60 \\
\hline G & 14.88 & 15.94 & 50.80 & 52.25 & 18.79 & 19.70 \\
\hline $\mathrm{H}$ & 12.44 & 13.52 & 48.35 & 51.68 & 19.03 & 20.45 \\
\hline $\mathrm{I}$ & 6.75 & 7.55 & 25.16 & 26.89 & 17.34 & 17.70 \\
\hline $\mathrm{J}$ & 2.58 & 3.00 & 35.47 & 35.29 & 2.24 & 3.21 \\
\hline
\end{tabular}

Table 5. Comparison of cord's maximum dose and mean dose between the beam delivery of ITV-IMRT and GateIMRT plan.

\begin{tabular}{cccccc}
\hline \hline \multirow{2}{*}{ Patients } & \multicolumn{2}{c}{ Cord mean-dose [Gy] } & & \multicolumn{2}{c}{ Cord max-dose [Gy] } \\
\cline { 2 - 3 } \cline { 5 - 6 } & Gate-IMRT & ITV-IMRT & & Gate-IMRT & ITV-IMRT \\
\hline A & 17.59 & 20.02 & & 38.84 & 41.91 \\
B & 9.32 & 11.27 & & 22.16 & 23.21 \\
C & 2.60 & 3.43 & & 18.08 & 19.75 \\
D & 27.51 & 29.67 & & 40.72 & 42.47 \\
E & 18.21 & 19.25 & & 38.11 & 39.27 \\
F & 11.35 & 11.96 & & 28.84 & 27.14 \\
G & 19.76 & 22.64 & & 41.81 & 42.49 \\
H & 18.30 & 19.06 & & 40.41 & 40.63 \\
I & 8.21 & 9.33 & & 41.33 & 43.85 \\
J & 9.53 & 10.15 & 30.31 & 32.10 \\
\hline \hline
\end{tabular}

\section{Discussion}

The PTV and OARs have virtually enlarged volumes that differ from those of real tumors and organs when the entire

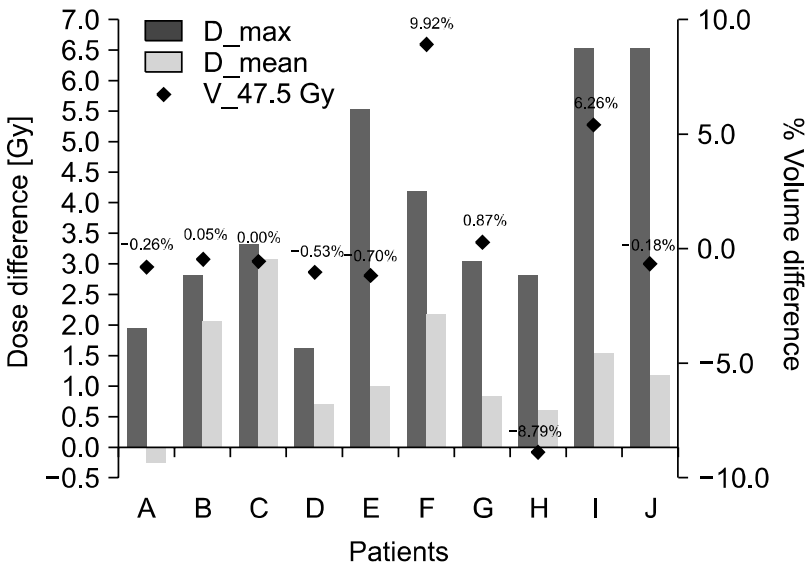

Fig. 6. Differences of PTV's DVH values between the ITV-IMRT beam delivery and Gate-IMRT plan at the major points.

motional range is considered during ITV-IMRT planning. This phenomenon makes it difficult to analyze the exact dose distributions in the actual PTV and OARs, although increased doses to the OARs can be assumed with ITV-IMRT, given the enlarged field size. In this study, the real dose distributions in 


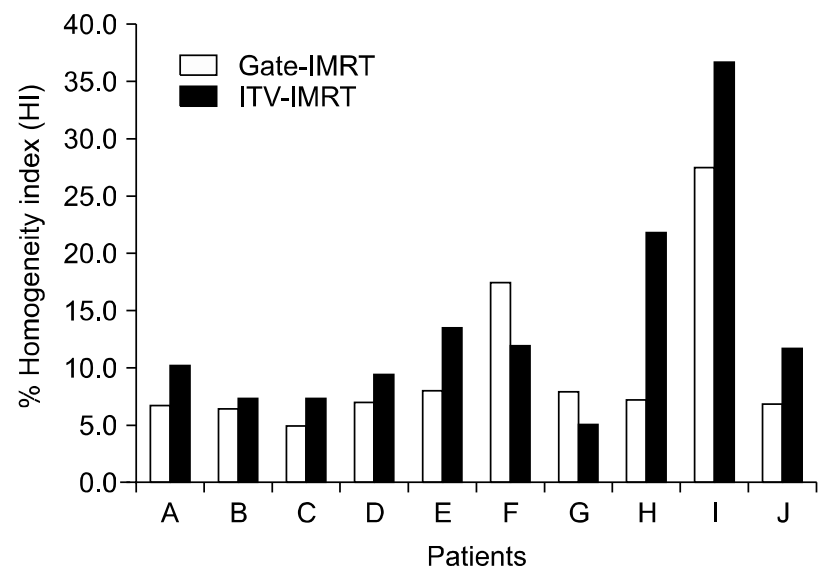

Fig. 7. Comparison of homogeneity index (HI) between the beam delivery of ITV-IMRT and Gate-IMRT plan.

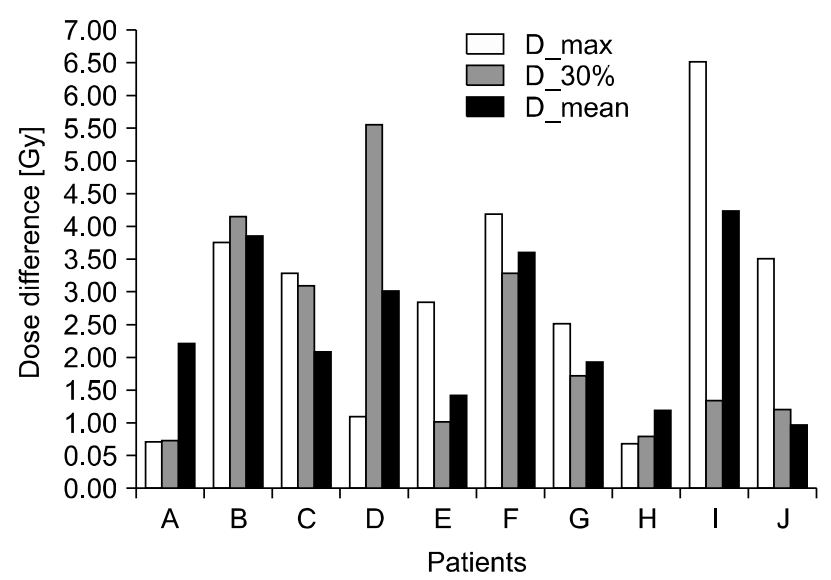

Fig. 8. Differences of liver's DVH values between the ITV-IMRT beam delivery and Gate-IMRT plan at the major points.

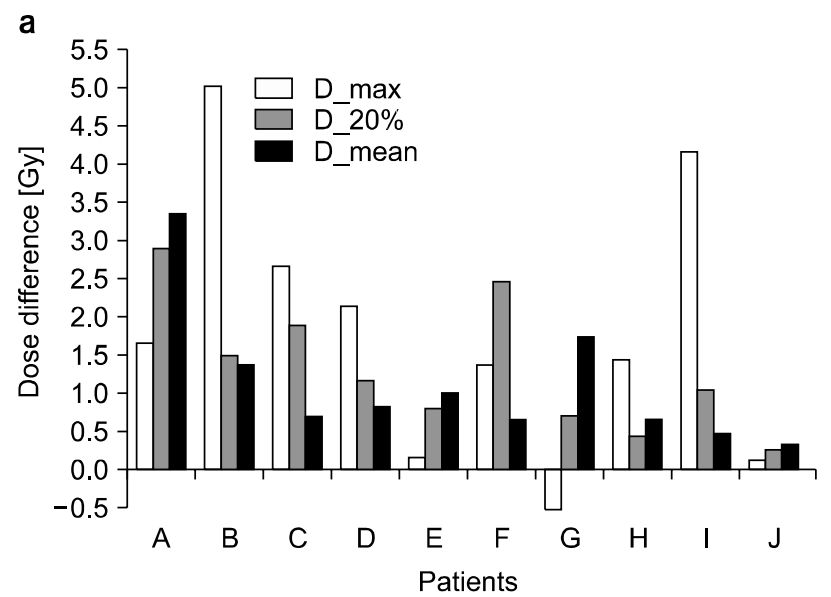

the actual volumes of the PTV and OARs during ITV-IMRT for liver cancer could be calculated based on the measured doses during beam delivery under respiratory motional conditions. We analyzed the recalculated doses through comparisons with the Gate-IMRT doses and verified that the delivered doses to the actual volumes of the PTV and OARs in ITVIMRT were somewhat higher than those calculated in the Gate-IMRT plan. Generally, the increased respiratory motional range caused the volume increases in the PTV and OARs, and we were able to confirm that higher actual doses were delivered to the PTV and OARs that moved within the enlarged field area.

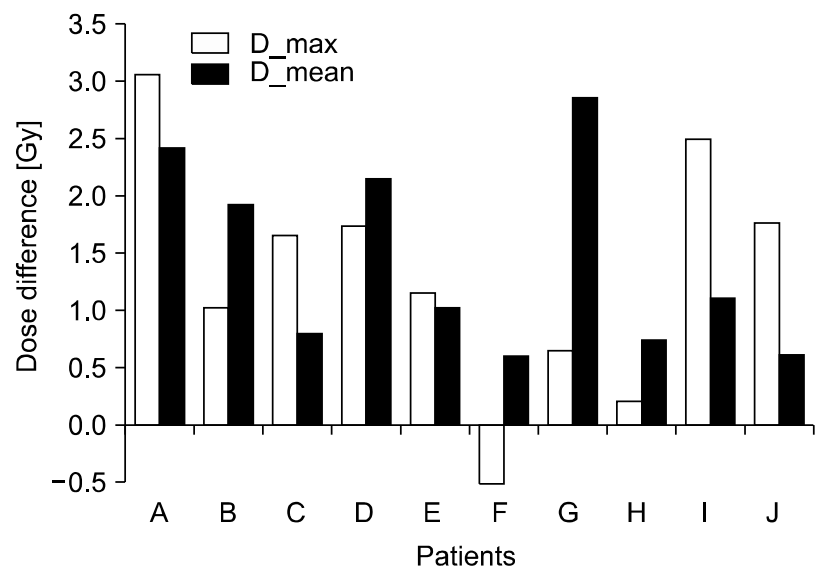

Fig. 10. Differences of maximum dose and mean dose of spinal cord between the ITV-IMRT beam delivery and Gate-IMRT plan.

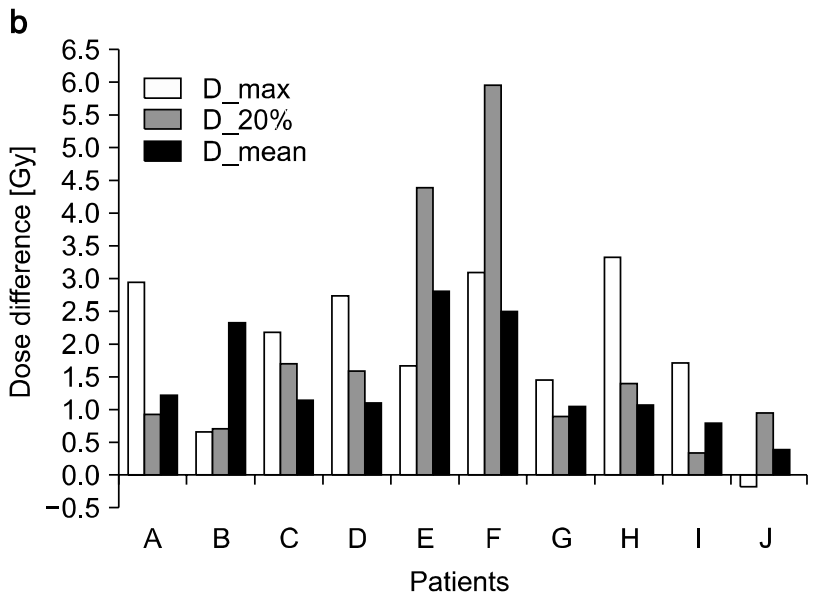

Fig. 9. Differences of kidney's DVH values between the ITV-IMRT beam delivery and Gate-IMRT plan at the major points. (a) Left kidney. (b) Right kidney. 
The correlation between the volume increases of the OARs and the respiratory motional range was negative, which might have been a result of the selection of a motional range in the area of the PTV's center that was not in the region of OARs. Although the exact 3-dimensional movements of the organs could not be simulated in this study, the motional effect could be evaluated sufficiently well by applying the largest motional change in the superior-inferior direction.

In this study, the accuracy of the dosimetric data calculated with the 3DVH program could be considered reliable because the dose calculation algorithm that incorporates the per-field dose measurement data using 3DVH has already been verified in many studies. ${ }^{15,16)}$

The average increase in the $\mathrm{D}_{\text {mean }}$ of the PTV was $1.30 \pm$ $0.96 \mathrm{~Gy}$, and the $\mathrm{D}_{\max }$ and $\mathrm{V}_{95 \%}$ of the PTV were also slightly elevated with ITV-IMRT delivery. Although the sufficient prescription dose coverage of the PTV could be considered a benefit of ITV-IMRT, the dose homogeneity in the PTV, evaluated using the HI, was inferior to that of the Gate- IMRT plan. This double-sided nature of the dose distribution to the PTV should be considered in ITV-IMRT cases.

Although the potential disadvantage of ITV-IMRT with respect to higher dose distribution to the OARs was again confirmed in this study, the dose increase rate was modest compared with the constraint criteria, and these increases should be evaluated from a biological point of view, rather than simply from a numerical dose increase. In other words, the dose increases should be analyzed with regard to the impact on the increased probability of complications in the OARs. The average increase in the $D_{\max }$ of the spinal cord with ITV-IMRT was $1.22 \pm 1.32 \mathrm{~Gy}$, which could be considered a meaningless increase if the maximum dose constraint for the spinal cord (45 Gy) was fulfilled. The important constraint value in the kidney, the $\mathrm{D}_{20 \%}$, increased with ITV-IMRT, and the average dose increase to both kidneys was $1.61 \pm 1.42$ Gy. The $\mathrm{D}_{30 \%}$ liver constraint also showed an increase with ITV-IMRT, and the average dose increase was $2.31 \pm 1.66 \mathrm{~Gy}$. The dose increases to the kidney and liver might be significant factors in failures of constraint fulfillment, and therefore the criteria for OAR constraints should be further restricted in the optimization process of ITV-IMRT plans.

The respiratory motional direction simulated in this study was only the superior-inferior direction, which could not simulate the real 3-dimensional movement of tumor. This limitation can be solved in the further study by the application of 3-dimensional moving phantom which can simulate tumor motion similarly with a real condition.

The problem of dose increases to the OARs during ITVIMRT can be solved by applying the Gate-IMRT method, which has a theoretical advantage with regard to the ideal dose distribution without a respiratory motional effect. However, Gate-IMRT also presents difficulties when attempting to realize the theoretical treatment conditions in actual clinical situations, including accurate MLC operation, gating system precision, stable patient respiration, and consistent organ motional correlation with the respiratory signals. When considering the increased treatment time consequent to the gating system application, Gate-IMRT cannot be considered a superior method with which to correct respiratory motional effects in actual clinical circumstances.

Therefore, it would be better to perform an analysis of the patient's respiratory patterns and constraints during the optimization process in order to select the proper IMRT method for areas of motion such as the liver and lung.

\section{Conclusions}

Dose distributions within the real volumes of the PTV and OARs during ITV-IMRT for liver cancer while under respiratory motional conditions could be acquired, and these data confirmed that higher irradiation doses were delivered to the OARs when compared to those calculated in the Gate-IMRT plan. However, the increased doses could be considered as minor risk factors if constraints were reinforced during the IMRT optimization process. Because Gate-IMRT cannot always be considered an ideal method with which to correct the respiratory motional effect, given the dosimetric variations in the gating system application and the increased treatment time, a prior analysis for optimal IMRT method selection should be performed while considering the patient's respiratory condition and IMRT plan results. 


\section{References}

1. Duan J, Shen S, Fiveash JB, et al: Dosimetric effect of respiration-gated beam on IMRT delivery. Med Phys 30(8):22412252 (2003)

2. Ahmed RS, Shen S, Ove R, et al: Intensity modulated with respiratory gating for radiotherapy of the pleural space. Med Dosim 32(1):16-22 (2007)

3. van der Geld YG, van Triest B, Verbakel WF, et al: Evaluation of four-dimensional computed tomography-based intensity-modulated and respiratory-gated radiotherapy techniques for pancreatic carcinoma. Int $\mathrm{J}$ Radiat Oncol Biol Phys 72(4):1215-1220 (2008)

4. Seco J, Sharp GC, Wu Z, et al: Dosimetric impact of motion in free-breathing and gated lung radiotherapy: a $4 \mathrm{D}$ Monte Carlo study of intrafraction and interfraction effects. Med Phys 35(1):356-366 (2008)

5. Chen $\mathrm{H}, \mathrm{Wu} A$, Brandner ED, et al: Dosimetric evaluations of the interplay effect in respiratory-gated intensity-modulated radiation therapy. Med Phys 36(3):893-903 (2009)

6. Kang H, Yorke ED, Yang J, et al: Evaluation of tumor motion effects on dose distribution for hypofractionated intensitymodulated radiotherapy of non-small-cell lung cancer. J Appl Clin Med Phys 11(3):78-89 (2010)

7. Cheong $\mathrm{KH}$, Kang SK, Lee M, et al: Evaluation of delivered monitor unit accuracy of gated step-and-shoot IMRT using a two-dimensional detector array. Med Phys 37(3):1146-1151 (2010)

8. Yoganathan SA, Maria Das KJ, Agarwal A, et al:
Performance evaluation of respiratory motion-synchronized dynamic IMRT delivery. J Appl Clin Med Phys 14(3):39-51 (2013)

9. Hugo GD, Agazaryan N, Solberg TD: An evaluation of gating window size, delivery method, and composite field dosimetry of respiratory-gated IMRT. Med Phys 29(11):2517-2525 (2002)

10. Xi M, Liu MZ, Deng XW, et al: Defining internal target volume (ITV) for hepatocellular carcinoma using four-dimensional CT. Radiother Oncol 84(3):272-278 (2007)

11. Xi M, Liu MZ, Zhang L, et al: How many sets of $4 D C T$ images are sufficient to determine internal target volume for liver radiotherapy? Radiother Oncol 92(2):255-259 (2009)

12. Reitz B, Parda DS, Colonias A, et al: Investigation of simple IMRT delivery techniques for non-small cell lung cancer patients with respiratory motion using 4DCT. Med Dosim 34(2): 158-169 (2009)

13. Speight R, Sykes J, Lindsay $R$, et al: The evaluation of a deformable image registration segmentation technique for semi-automating internal target volume (ITV) production from 4DCT images of lung stereotactic body radiotherapy (SBRT) patients. Radiother Oncol 98(2):277-283 (2011)

14. Wu Q, Mohan R, Morris M, et al: Simultaneous integrated boost intensity modulated radiotherapy for locally advanced head-and-neck squamous cell carcinomas. I: dosimetric results. Int J Radiat Oncol Biol Phys 56(2):573-585 (2003)

15. Olch AJ: Evaluation of the accuracy of $3 D V H$ software estimates of dose to virtual ion chamber and film in composite IMRT QA. Med Phys 39(1):81-86 (2012)

16. Carrasco $P$, Jornet $N$, Latorre $A$, et al: $3 D D V H-$ based metric analysis versus per-beam planar analysis in IMRT pretreatment verification. Med Phys 39(8):5040-5049 (2012) 


\title{
간암 환자의 세기조절방사선치료 시 호흡에 의한 움직임 조건에서 측정된 조사면 별 선량결과를 기반으로 재계산한 체내 선량분포 평가
}

\author{
*화순전남대학교병원 방사선종양학과, ${ }^{\dagger}$ 전남대학교 의과대학 방사선종양학교실 \\ 송주영 $^{\dagger} \cdot$ 김용협* $\cdot$ 정재욱* $\cdot$ 윤미선 ${ }^{\dagger} \cdot$ 안성자 $^{\dagger} \cdot$ 정웅기 ${ }^{\dagger} \cdot$ 남택근 $^{\dagger}$
}

\begin{abstract}
내부표적체적을 기반으로 계획된 간암 환자의 세기조절방사선치료에서 호흡에 의한 장기의 움직임 영향을 적용하여 체 내 실제 종양 부피와 중요 장기 부피에서의 선량분포를 재계산하고, 호흡동조 방식의 세기조절방사선치료 계획 결과와 비교를 통한 선량적 특성을 분석하였다. 내부표적체적은 MIM 프로그램을 사용하여 형성하였고, 호흡에 의한 장기 움직 임을 모사할 수 있는 구동 팬텀을 사용하였다. 체내 선량분포는 세기조절방사선치료의 품질보증 과정에서 2차원 다이오 드 검출기 배열 장치인 MapCHECK2로 측정한 조사면 별 측정 결과를 기반으로 $3 \mathrm{DVH}$ 프로그램으로 재계산 하였다. 내 부표적체적 기반의 세기조절방사선치료 수행 시 계획표적체적에 충분히 처방선량이 조사되었지만, 선량의 균일도는 호 흡동조 방식의 세기조절방사선치료와 비교 시 열등한 결과를 보였다. 상대적으로 더 큰 조사면을 사용하는 내부표적체 적 기반의 세기조절방사선치료에서 손상위험장기체적에 더 높은 선량이 조사됨을 확인할 수 있었지만, 척수에 증가된 선량은 부작용 발생확률에 큰 영향을 주지 않는 적은 양이었고, 정상 간이나 신장 부위의 증가된 선량도 최적화 과정에 서 좀 더 선량감소 조건을 강화한다면 큰 영향이 없을 것으로 평가되었다. 호흡동조 방식의 세기조절방사선치료가 치료 계획에서는 더 좋은 선량분포를 보이고 있으나, 실제 구현 과정에서 다엽콜리메이터의 움직임 오류로 인한 선량의 오차 와 치료시간의 증가 측면의 단점이 있으므로, 환자 호흡 상태 및 손상위험장기의 선량제한 값에 대한 사전 분석을 통해 환자 별 최적의 세기조절방사선치료 기법을 선정하여 적용하는 것이 타당하다고 생각된다.
\end{abstract}

중심단어: 장기 움직임, 세기조절방사선치료, 내부표적체적, 호흡연동방사선치료, $3 \mathrm{DVH}$ 